\title{
Naltrexone sustained-release/bupropion sustained-release for the management of obesity: review of the data to date
}

This article was published in the following Dove Press journal:

Drug Design, Development and Therapy

18 September 2014

Number of times this article has been viewed

\section{Assumpta Caixàs \\ Lara Albert \\ Ismael Capel \\ Mercedes Rigla}

Endocrinology and Nutrition Department, Parc Tauli Sabadell University Hospital, Autonomous University of Barcelona, Barcelona, Spain
Correspondence:Assumpta Caixàs Endocrinology and Nutrition Department, Parc Tauli Sabadell University Hospital, Autonomous University of Barcelona, c/o Parc Taulí no I, 08208 Sabadell, Spain Tel +34 937458412

Fax +34937 I60646

Email acaixas@tauli.cat
Abstract: Obesity is an emerging disease worldwide. Changes in living habits, especially with increased consumption of high-calorie foods and decreased levels of physical activity, lead to an energy imbalance that brings weight gain. Overweight and obesity are major risk factors for several chronic diseases (including cardiovascular diseases, diabetes, and cancer), reduce quality of life, and are associated with higher mortality. For all these reasons, it is of the utmost importance that the trend be reversed and obese people enabled to lose weight. It is known that eating a healthy diet and exercising regularly can help prevent obesity, but data show that in many cases these steps are not enough. This is the reason why, over the last few decades, several antiobesity drugs have been developed. However, the disappointing results demonstrated for the vast majority of them have not discouraged the pharmaceutical industry from continuing to look for an effective drug or combination of drugs. The systematic review presented here focuses on naltrexone sustained-release/bupropion sustained-release combination (Contrave $\left.{ }^{\circledR}\right)$. We conclude from the current published reports that its effectiveness in the treatment of obesity can be estimated as a placebo-subtracted weight loss of around $4.5 \%$. This weight reduction is moderate but similar to other antiobesity drugs. The safety profile of this combination is acceptable, despite additional data regarding cardiovascular disease being needed.

Keywords: Contrave, weight loss, overweight, cardiovascular disease, diabetes, cancer

\section{Background}

"Obesity", defined as a body mass index (BMI) of $\geq 30 \mathrm{~kg} / \mathrm{m}^{2}$, is an emergent chronic disease across the world. Based on the latest estimates, in European Union countries, overweight affects $30 \%-70 \%$ of adults and obesity affects $10 \%-30 \%$ of adults. Data from the National Health and Nutrition Examination Survey show that in the USA more than one-third of adults and almost $17 \%$ of children and adolescents were obese in $2009-2010^{1}$ and linear time trend forecasts suggest that, by $2030,51 \%$ of the population will be obese. ${ }^{2}$ Moreover, the estimated annual medical cost of obesity in the USA was US\$147 billion in 2008. ${ }^{3}$ This is due in part to the higher morbidity associated with obesity in hypertension, type 2 diabetes, coronary heart disease, stroke, gallbladder disease, osteoarthritis, sleep apnea, and some types of cancer (endometrial, breast, prostate, and colon). Obesity is also associated with pregnancy complications, menstrual irregularities, hirsutism, stress incontinence, and psychological disorders (depression). ${ }^{4}$ Mortality increases progressively once the overweight threshold is crossed. ${ }^{5}$ The dramatic increase in obesity prevalence during the past years has turned this disorder into a major health problem and prompted authorities to take action to decrease the impact of its consequences. 
Traditional treatments based on lifestyle modification by changing patterns of diet and increasing physical activity are usually the first and basic steps in obesity treatment, but, in most cases, these only produce short-term weight loss. That fact reflects the necessity for other therapeutic strategies, such as antiobesity drugs or bariatric surgery.

The ideal antiobesity drug would produce sustained weight loss with minimal side effects and may account for different mechanisms of action: appetite suppression, including eating behavior and food intake; interference with nutrient absorption; or increases in metabolism and energy expenditure. However, the mechanisms that regulate energy balance have a substantial overlap with other physiological functions and are influenced by social, hedonic, and psychological factors that limit the effectiveness of pharmacological interventions. It is not therefore surprising that antiobesity drug-discovery programs have finished with failures in clinical development and withdrawals due to adverse effects.

Recent improvements in the understanding of peptidergic signaling of hunger and satiety from the gastrointestinal tract mediated by ghrelin, cholecystokinin, peptide YY, and glucagon-like peptide-1 (GLP-1) and of homeostatic mechanisms related to leptin and its upstream pathways in the hypothalamus have opened up new possibilities. ${ }^{6}$ Although some peptidergic signalers and homeostatic mechanisms have now reached clinical development, it is uncertain whether they will satisfy all the requirements to be an effective antiobesity drug. ${ }^{7}$

At present, orlistat, an intestinal lipase inhibitor, is the only long-term antiobesity drug approved by both the European Medicines Agency and the US Food and Drug Administration (FDA) in the USA. ${ }^{8}$ Phentermine, diethylpropion (amfepramone), benzphetamine, and phendimetrazine, all of them amphetamine-like analogs that increase the release of norepinephrine, are also approved in the USA as antiobesity agents for the short-term treatment of obesity. In Europe, phentermine was withdrawn in 1999 and the others have never been approved. Lorcaserin (Belviq ${ }^{\circledR}$; Arena Pharmaceuticals, Zofingen, Switzerland) a 5- $\mathrm{HT}_{2 \mathrm{C}}$ receptor agonist, was also approved by the FDA in 2012 after being re-filed. ${ }^{7}$

In other therapeutic fields, such as diabetes and hypertension, lower doses of multiple agents targeting different pathways often yield better results than strategies that modify one pathway alone. Some combination approaches using two kinds of molecules have now reached clinical trial (Table 1) and one of them, qnexa (Qsymia ${ }^{\circledR}$; Vivus, Mountain View, CA, USA), a combination of phentermine and topiramate sustained-release (SR), has already been approved by the FDA. Nevertheless, body-weight control achieved using these drugs is far from the sustained weight loss and its consequent amelioration of comorbidities following any of the bariatric surgical procedures. ${ }^{9}$

This review focuses on current treatment with the combination of naltrexone/bupropion SR (Contrave ${ }^{\circledR}$; Orexigen Therapeutics, La Jolla, CA, USA) that was turned down by the FDA owing to potential cardiovascular risk. Nevertheless, it seems probable that it will be re-filed in the near future when the randomized, double-blind, placebocontrolled Light Study assesses the actual risk of major cardiovascular events. The final decision is expected by the end of 2014 based on the interim analysis, although the study will not really finish until 2017.

\section{Methods}

A systematic search strategy was developed to identify publications in both MEDLINE ${ }^{\circledR}$ (National Library of Medicine, Bethesda, MD) and the Cochrane library (The Cochrane Collaboration, Oxford, UK). The terms "obesity", "naltrexone", "bupropion", and "Contrave" were incorporated into an electronic search strategy. We were able to find 44 manuscripts. Twenty of these were general revisions about obesity treatment or an update on antiobesity drugs that included or mentioned naltrexone or bupropion. ${ }^{6,8-26}$ The rest (24 of them) were about the combination of naltrexone and bupropion. One of them was exclusively in rodent models ${ }^{27}$ and the rest were mainly in humans ${ }^{28-50}$ in the form of reviews, letters, editorials, posters, or original articles of the clinical trials performed to test this combined drug. We comment on the most relevant in the present review.

\section{Central nervous system appetite and satiety pathways at a glance}

The central mechanisms of hunger and satiety are regulated by the arcuate nucleus of the hypothalamus, which receives signals by several hormones and peptides synthesized mainly by the gut and adipose tissue, like insulin, leptin, ghrelin, peptide PYY, cholecystokinin, GLP-1, and others. $^{51}$

The arcuate nucleus is divided into a lateral and a medial portion which work in opposite pathways but transmit signals to the same areas of the brain. ${ }^{28}$ The lateral neurons synthesize and secrete neuropeptide $\mathrm{Y}$ and Agouti-related protein, with orexigenic actions, while medial neurons produce proopiomelanocortin (POMC) $)^{44}$ and cocaine and amphetamineregulated transcript that induce anorexigenic actions. POMC 
Table I Antiobesity drugs in development

\begin{tabular}{|c|c|c|}
\hline Name or code & Mechanism of action & Current status \\
\hline \multicolumn{3}{|l|}{ Monotherapy } \\
\hline Lorcaserin & $5-\mathrm{HT}_{2 \mathrm{C}}$ receptor agonist & FDA approved 2012 \\
\hline Cetilistat & Pancreatic lipase inhibitor & NDA filed in Japan \\
\hline Liraglutide & Long-acting GLP-I analog & Phase III ongoing \\
\hline Velneperit & Neuropeptide Y5 subtype receptor antagonist & Phase II completed \\
\hline$J N J-16269110$ & MTP inhibitor & Phase II completed \\
\hline TTP-435 & AgRP inhibitors & Phase II completed \\
\hline Beloranib & MetAP-2 inhibitor & Phase II ongoing \\
\hline Oxyntomodulin & Dual agonist of GLPIR and GCGR & Phase II ongoing \\
\hline GSKI52I498 & $\mu$-opioid inverse agonist & Phase I completed \\
\hline GSK598809 & Dopamine D3 receptor antagonist & Phase I completed \\
\hline \multirow[t]{2}{*}{ PF-0497I 729} & Selective inhibitor of the sodium-dependent & Phase I completed \\
\hline & glucose co-transporter 2 & \\
\hline PF-04620II 0 & Selective DGAT-I inhibitor & Phase I completed \\
\hline LY377604 & Selective $\beta 3$ adrenergic receptor agonist & $\begin{array}{l}\text { Clinical trial terminated (discontinued?) } \\
\text { due to results from recent nonclinical } \\
\text { studies }\end{array}$ \\
\hline Betahistine & $\begin{array}{l}\text { Histamine subtype receptor } \mathrm{HI} \text { agonist } \\
\text { and } \mathrm{H} 3 \text { subtype receptor antagonist }\end{array}$ & Failure because of inconsistent results \\
\hline Taranabant & Cannabinoid receptor inverse agonist & Failure because of psychiatric side effects \\
\hline MK-0493 & Melanocortin receptor 4 & Failure because of limited efficacy \\
\hline \multicolumn{3}{|l|}{ Combination } \\
\hline Phentermine/topiramate & Amphetamine derivative & FDA approved 2012 \\
\hline Zonisamide/bupropion (Empatic ${ }^{\mathrm{TM}}$ ) & $\begin{array}{l}\text { CA inhibitor/dopamine } \\
\text { and noradrenaline reuptake inhibitor }\end{array}$ & Phase II completed \\
\hline Tesofensine & Triple monoamine reuptake inhibitor & Phase III ongoing \\
\hline Bupropion/naltrexone (Contrave ${ }^{\circledR}$ ) & 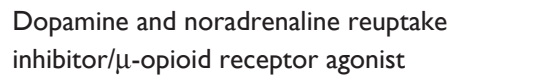 & Phase III ongoing \\
\hline Dov21947 & Triple monoamine reuptake inhibitor & Phase II \\
\hline Obinepitide & $\begin{array}{l}\text { Neuropeptide Y2 + Y4 subtype receptor } \\
\text { agonist }\end{array}$ & Phase II: failure for unknown reasons \\
\hline Pramlintide/metreleptin & Amylin analog/leptin analog & Phase II: failure for commercial reasons \\
\hline
\end{tabular}

Abbreviations: 5-HT, 5-hydroxytryptamine; AgRP, Agouti-related protein; $\beta 3$, beta-3; CA, carbonic anhydrase; DGAT-I, diglyceride acyl transferase I; FDA, US Food and Drug Administration; GCGR, glucagon receptor gene; GLP-I, glucagon-like peptide I; GLPIR, glucagon-like peptide I receptor; $\mu$, mu; MetAP-2, methionine aminopeptidase 2; MTP, microsomal triglyceride transfer protein; NDA, non-disclosure agreement.

is rapidly cleaved into $\alpha$-MSH and $\beta$-endorphin. $\alpha$-MSH acts at melanocortin MC3 and MC4 receptors in the hypothalamus and the rest of the brain, inducing satiety and inhibiting food intake, as well as increasing resting energy expenditure. On the other hand, $\beta$-endorphin, an endogenous opioid, autoinhibits the POMC pathway, and its excess in rodents leads to increased food intake. ${ }^{28}$

At fasting state, ghrelin, the only peripheral orexigenic peptide, stimulates the lateral neurons of the arcuate nucleus and initiates food intake; by contrast, at postprandial state, all the other mentioned peripheral hormones and peptides stimulate the medial arcuate nucleus. From both sides of the arcuate nucleus, axons emerge to other hypothalamus parts such as paraventricular nucleus, lateral hypothalamus, and perifornical area. From them, more complicated pathways, still under investigation, pass through the nucleus of the solitary tract to the vagus nerve and the superior cervical ganglion returning the input to gut to inhibit mechanical and secretional stimuli and to close the loop (Figure 1).

\section{Bupropion}

"Bupropion" is a dopamine and norepinephrine reuptake inhibitor mainly used for the treatment of depression and as an aid in smoking cessation. ${ }^{26}$ Many clinical observations have been made indicating that bupropion has an anorexigenic activity which has been related to the stimulation of POMCproducing neurons in the arcuate nucleus of the hypothalamus. These neurons release $\alpha-\mathrm{MSH}$, which acts on MC4 receptors, decreasing food intake and increasing energy expenditure. ${ }^{30}$ The effect of bupropion on POMC-producing neurons has been shown in animal models, ${ }^{28}$ while some clinical studies ${ }^{52,53}$ have displayed a modest weight reduction effect of bupropion in monotherapy, and, for that reason, it did not meet FDA criteria for approval as a monotherapy for obesity. 


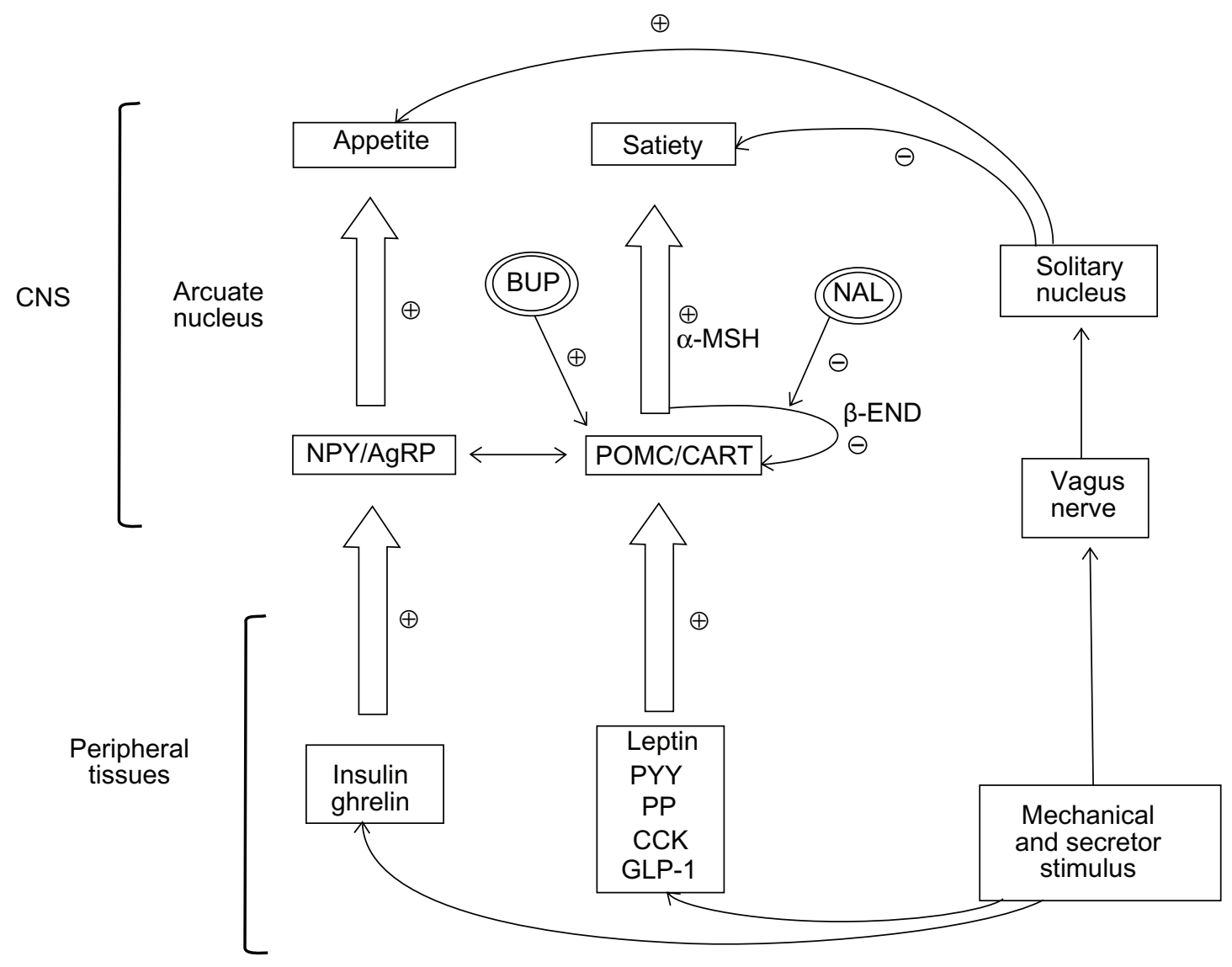

Figure I Central and peripheral mechanisms of appetite and satiety and site of action of bupropion and naltrexone.

Abbreviations: $\alpha$-MSH, $\alpha$-melanocyte-stimulating hormone; AgRP, Agouti-related protein; $\beta$-END, $\beta$-endorphin; BUP, bupropion; CART, cocaine and amphetamine-regulated transcript; CCK, cholecystokinin; CNS, central nervous system; GLP-I, glucagon-like peptide-I; NAL, naltrexone; NPY, neuropeptide Y; POMC, pro-opiomelanocortin; PP, pancreatic polypeptide; PYY, peptide YY.

As mentioned, POMC-producing neurons also release beta-endorphin which has an autoinhibitory feedback and decreases the anorexigenic effect of $\alpha-\mathrm{MSH}$. This autoinhibitory mechanism may disturb the anorexigenic effect of $\alpha$-MSH and might contribute to the limited antiobesity effect of bupropion in monotherapy. ${ }^{44}$

\section{Naltrexone}

"Naltrexone" is an opioid receptor antagonist mainly used in the treatment of alcohol and opioid addictions. ${ }^{54}$ It is metabolized by the hepatic enzyme dihydrodiol dehydrogenase to its active metabolite $6 \beta$-naltrexol. Both naltrexone and $6 \beta$-naltrexol are competitive antagonists at the $\mu$ - and $\kappa$-opioid receptors in the central nervous system. ${ }^{55}$ In 1979, the observation that naloxone, another opioid receptor antagonist, produced a significant reduction in short-term food intake in rats proved the role of this kind of drug in eating behavior. ${ }^{56}$ Subsequent studies led to the "opioid-palatability hypothesis", which suggests that opioid release plays an important role in the expression of food palatability ${ }^{57}$ and may decrease sweet food pleasantness. ${ }^{58}$ Given these observations, naltrexone was seen as a potential obesity treatment and several studies have been performed and published since the early 1980s. However, the results of these studies ${ }^{59-64}$ were disappointing, because naltrexone monotherapy was associated with minimal or no weight loss. ${ }^{29}$ The limited efficacy of a single obesity agent such as naltrexone might be explained because of the various different mechanisms regulating caloric intake and body weight. ${ }^{65}$ Therefore, a combination of drugs would be a better option.

\section{Contrave ${ }^{\circledR}$ combination naltrexone/ bupropion SR}

"Contrave" is a fixed-dose combination of naltrexone and bupropion. The idea of associating an antagonist of the opioid receptors, in order to block the autoinhibitory feedback, arises as a good way to enhance the anorexigenic effect of bupropion. The effect of the combination is synergistic, and the results are at least fully additive in all electrophysiological 
studies. ${ }^{28}$ Blunting the hypothalamic reactivity to food cues while enhancing the activation of regions involved in selfcontrol and internal awareness might underlie its therapeutic benefits in obesity. ${ }^{50}$

\section{Preclinical studies}

In vitro electrophysiological studies in mouse brain slices have demonstrated the stimulatory effect of bupropion and naltrexone, independently, over the POMC neurons. When a combination of these two drugs was used, the stimulatory effect was greater. ${ }^{28}$ In the same publication, an in vivo study in obese mice showed a significant reduction in food intake when a combination of bupropion and naltrexone was used, in front of the moderate effect observed when these drugs were administered independently. These observations strongly support the hypothesis of a synergic anorexigenic effect of bupropion and naltrexone.

Another study in mice ${ }^{27}$ explored the use of bupropion/ naltrexone associated with amylin. The combination therapy exerted additive effects to reduce cumulative food intake, body weight, and fat mass. The experiment was performed with pair-fed animals, which were mice with the same calorie intake as those treated with bupropion/naltrexone and amylin. Both groups showed a similar body-weight loss but the pharmacological treated group lost $68 \%$ more fat and better maintained lean mass, so this additive effect could be attributed to the pharmacological effect and not to calorie restriction.

\section{Major clinical trials}

The major clinical trials are summarized in Table 2. The first human trial of this combination for the treatment of obesity was performed in the first Phase II clinical trial conducted in 2004 and published in 2008. ${ }^{30}$ Two hundred and thirty eight subjects with a BMI between 30 and $40 \mathrm{~kg} / \mathrm{m}^{2}$ were blindly randomized to one among four treatment groups: placebo $(\mathrm{P})$, bupropion SR $300 \mathrm{mg} /$ day (B), naltrexone immediate release $50 \mathrm{mg} /$ day $(\mathrm{N})$, or the combination of bupropion plus naltrexone $(\mathrm{B}+\mathrm{N})$. The primary endpoint was the percentage body-weight reduction at week 16, and, for patients in groups $\mathrm{B}$ and $\mathrm{B}+\mathrm{N}$, there was an extension period to week 24 . At week 16 , the adjusted percentage of body-weight change, considering an intention-to-treat (ITT) analysis, was -1.0, -2.0, -3.6 , and $-4.0 \mathrm{~kg}$ for the $\mathrm{P}, \mathrm{N}, \mathrm{B}$ and $\mathrm{B}+\mathrm{N}$ groups, respectively $(P<0.001)$. In those patients who completed the overall protocol $(n=146)$, the adjusted percentage of body-weight change difference between the $\mathrm{P}$ and $\mathrm{B}+\mathrm{N}$ groups was more pronounced $(-1.0 \mathrm{vs}-4.8 ; P<0.001)$. In the extension phase, at week 24 , the adjusted percentage of body-weight change, with an ITT analysis, was -4.0 versus -5.2 for the B and B + $\mathrm{N}$ groups, respectively ( $P$ nonsignificant). In the completers group ( $\mathrm{n}=59)$, the unadjusted percentage of body-weight

Table 2 Major clinical trials assessing bupropion plus naltrexone as obesity treatment

\begin{tabular}{|c|c|c|c|c|}
\hline Trial phase & Publication & Subjects & Placebo-subtracted weight loss & Safety \\
\hline II & Greenway et $\mathrm{al}^{28}$ & $\begin{array}{l}\mathrm{n}=238 \\
\text { BMI } 30-40 \mathrm{~kg} / \mathrm{m}^{2}\end{array}$ & Week I6 (ITT analysis): $-3.00 \%$ & $\begin{array}{l}\text { No SAEs } \\
\text { AE: nausea }\end{array}$ \\
\hline II & Greenway et $\mathrm{al}^{31}$ & $\begin{array}{l}\mathrm{n}=419 \\
\mathrm{BMI} 30-40 \mathrm{~kg} / \mathrm{m}^{2}\end{array}$ & $\begin{array}{l}\text { Week } 24 \text { (ITT analysis): }-4.65 \% \\
\text { (with bupropion SR } 400 \mathrm{mg} / \text { day } \\
\text { plus naltrexone immediate } \\
\text { release } 32 \mathrm{mg} / \text { day) }\end{array}$ & $\begin{array}{l}\text { One possibly drug-related SAE } \\
\text { (atrial fibrillation) } \\
\text { AEs: nausea, headache, } \\
\text { dizziness }\end{array}$ \\
\hline III & $\begin{array}{l}\text { Greenway et } \mathrm{al}^{36} \\
\text { COR-I }\end{array}$ & $\begin{array}{l}\mathrm{n}=\mathrm{I}, 742 \\
\text { Uncomplicated BMI } 30-45 \mathrm{~kg} / \mathrm{m}^{2} \\
\text { or BMI } 27-45 \mathrm{~kg} / \mathrm{m}^{2} \text { plus } \\
\text { dyslipidemia or hypertension }\end{array}$ & $\begin{array}{l}\text { Duration } 56 \text { weeks but only } 50.00 \% \\
\text { of patients completed the study } \\
\text { Primary analysis: }-4.80 \% \\
\text { (with bupropion } 360 \mathrm{mg} \text { plus } \\
\text { naltrexone SR } 32 \mathrm{mg} / \text { day) }\end{array}$ & $\begin{array}{l}\text { No SAEs related to investigational } \\
\text { drug } \\
\text { AEs: nausea, headache, constipation }\end{array}$ \\
\hline III & $\begin{array}{l}\text { Wadden et } \mathrm{al}^{46} \\
\text { COR-BMOD }\end{array}$ & $\begin{array}{l}\mathrm{n}=793 \\
\text { Uncomplicated BMI } 30-45 \mathrm{~kg} / \mathrm{m}^{2} \\
\text { or BMI } 27-45 \mathrm{~kg} / \mathrm{m}^{2} \text { plus } \\
\text { dyslipidemia or hypertension }\end{array}$ & $\begin{array}{l}\text { Week } 56 \text { (ITT analysis): }-4.20 \% \\
\text { (with BMOD plus a combination } \\
\text { of naltrexone SR } 32 \mathrm{mg} / \text { day } \\
\text { and bupropion } 360 \mathrm{mg} / \text { day) }\end{array}$ & $\begin{array}{l}\text { Two possibly drug-related } \\
\text { SAEs (cholecystitis) } \\
\text { AEs: nausea, constipation, } \\
\text { dizziness, dry mouth, tremor, } \\
\text { abdominal pain, tinnitus }\end{array}$ \\
\hline III & $\begin{array}{l}\text { Apovian et } \mathrm{al}^{48} \\
\text { COR-II }\end{array}$ & $\begin{array}{l}\mathrm{n}=\mathrm{I}, 496 \\
\text { Uncomplicated BMI } 30-45 \mathrm{~kg} / \mathrm{m}^{2} \\
\text { or BMI } 27-45 \mathrm{~kg} / \mathrm{m}^{2} \text { plus } \\
\text { dyslipidemia or hypertension }\end{array}$ & $\begin{array}{l}\text { Week } 28 \text { (ITT analysis): }-4.60 \% \\
\text { (with bupropion } 360 \mathrm{mg} / \text { day plus } \\
\text { naltrexone SR } 32 \mathrm{mg} / \text { day) }\end{array}$ & $\begin{array}{l}\text { 2.1\% of patients in NB32 } \\
\text { group had an SAE, } \\
\text { including one episode } \\
\text { of seizures and one myocardial } \\
\text { infarction } \\
\text { AEs: nausea, headache, constipation }\end{array}$ \\
\hline
\end{tabular}

Abbreviations: AE, adverse event; BMI, body mass index; BMOD, behavior-modification program; COR-I, Contrave Obesity Research I; COR-II, Contrave Obesity Research II; COR-BMOD, Contrave Obesity Research and Behaviour Modification; ITT, intention to treat; NB32, naltrexone SR 32 mg/day plus bupropion 360 mg/day; SAE, serious adverse event; SR, sustained-release. 
change was -4.0 versus -6.5 for the $\mathrm{B}$ and $\mathrm{B}+\mathrm{N}$ groups, respectively $(P<0.05)$. Thus, a sustained weight reduction, without evidence of an efficacy plateau, was observed with the combination of $\mathrm{B}+\mathrm{N}$. Completers of $\mathrm{B}+\mathrm{N}$ diverged from $\mathrm{P}$ and $\mathrm{N}$ groups at week 16 and from $\mathrm{B}$ group at week 24. Regarding safety endpoints, there were no drug-related serious adverse effects and the most common reported adverse event (AE) was nausea with an incidence of $34.5 \%$ in group $\mathrm{N}, 31.4 \%$ in group $\mathrm{B}+\mathrm{N}$, and $1.9 \%$ in group $\mathrm{P}$.

A second Phase II clinical trial, especially focused on finding the optimal naltrexone dose, was conducted between 2005 and 2006 and published in 2009. ${ }^{31}$ Four hundred and nineteen patients with a BMI between 30 and $40 \mathrm{~kg} / \mathrm{m}^{2}$ participated in this study. They were blinded randomized to placebo (P), bupropion SR $400 \mathrm{mg} /$ day (B), naltrexone immediate release $48 \mathrm{mg}$ /day (N48), bupropion SR $400 \mathrm{mg}$ /day plus naltrexone immediate release $16 \mathrm{mg} /$ day (NB16), bupropion SR $400 \mathrm{mg} /$ day plus naltrexone immediate release $32 \mathrm{mg} /$ day (NB32) and bupropion $400 \mathrm{mg} /$ day plus naltrexone immediate release $48 \mathrm{mg}$ /day (NB48). The primary endpoint was the percentage of weight loss at week 24, and the ITT analysis showed a placebo-subtracted weight loss of $-4.62 \%$ for NB16, $-4.65 \%$ for NB32 and $-3.53 \%$ for NB48 $(P<0.001)$. Weight loss was also significantly greater with all combinations of bupropion and naltrexone versus monotherapy, with the exception of $B$ versus NB48. There was a high attrition rate, mainly due to nausea, in the group of NB48 (only 37\% completed the 24 weeks of treatment), which clearly limited its effectiveness according to the ITT analysis. In the extension study, at week 48 , the percentages of weight loss were $-2.7 \%$ for $\mathrm{B},-5.5$ for NB16, $-6.6 \%$ for NB32 and -5.0 for NB48 $(P<0.05)$. Regarding safety endpoints, there were eight serious adverse events (SAEs) during the 48 weeks. Only one, a case of atrial fibrillation, was felt to be possibly related to the study drug by the investigator. The most common adverse effect was nausea, which was clearly related to the dose of naltrexone. The incidence of this effect reached $41 \%$ in the NB48 group.

Orexigen Therapeutics, developer of the commercial brand Contrave (bupropion plus naltrexone SR), started a Phase III research program called "Contrave Obesity Research" (COR). The COR-I study, the first of the program, was conducted between 2007 and 2009 and published in $2010 .{ }^{36}$ The participating subjects had either uncomplicated obesity with a BMI between 30 and $45 \mathrm{~kg} / \mathrm{m}^{2}$ or a BMI of $27-45 \mathrm{~kg} / \mathrm{m}^{2}$ associated with dyslipidemia or arterial hypertension. A total of 1,742 patients were randomized into one of the three treatment groups: bupropion $360 \mathrm{mg}$ plus naltrexone SR $32 \mathrm{mg}$ /day (NB32), bupropion $360 \mathrm{mg}$ plus naltrexone SR $16 \mathrm{mg} /$ day (NB16), or placebo (P). The primary endpoints were the percentage of weight loss and the proportion of patients achieving a weight loss of $5 \%$ or greater. Only $50 \%$ completed the 56 weeks of treatment. The primary analysis included all randomized patients with a post-baseline weight measurement $(n=1,453)$. The percentage of weight loss was $-1.3 \%$ in the $\mathrm{P}$ group, $-5.0 \%$ in the NB16 group, and $-6.1 \%$ in the NB32 group $(P<0.001)$. There were nine SAEs in the NB32 group, nine in the NB16 group, and eight in the $\mathrm{P}$ group. None of them was related to the investigational drug according to the researcher's reports. The most frequently reported $\mathrm{AE}$ was nausea, with an incidence of $29.8 \%$ in the two NB groups combined, in front of $5.3 \%$ in the P group.

Another Phase III study in the COR program was published in 2011. ${ }^{46}$ In this trial, the pharmacological intervention was carried out together with an intensive behavior-modification program (BMOD), following the recommendation of an expert panel of the National Institutes of Health. ${ }^{4}$ Patients $(n=793)$ with an uncomplicated obesity (BMI between 30 and $45 \mathrm{~kg} / \mathrm{m}^{2}$ ) or with a BMI between 27 and $45 \mathrm{~kg} / \mathrm{m}^{2}$ plus dyslipidemia or hypertension were randomized at a 1:3 ratio to $\mathrm{BMOD}$ plus placebo or BMOD plus a combination of naltrexone SR $32 \mathrm{mg} /$ day and bupropion $360 \mathrm{mg} /$ day (NB32). The coprimary endpoints were percentage of change in weight and the proportion of participants who lost $\geq 5 \%$ of the baseline weight at week 56. With an ITT analysis, at week 56, weight loss was $5.1 \%$ with placebo plus BMOD versus $9.3 \%$ with NB32 + BMOD $(P<0.001)$. Completers analysis revealed weight losses of $7.3 \%(n=106)$ versus $11.5 \%(n=301)$, respectively $(P<0.001)$. There were two SAEs potentially related to the study drug, consisting of cholecystitis. The most common adverse effect was nausea (incidence of $34 \%$ in the NB32 group). Other adverse effects that were more frequently reported in the NB32 group were constipation, dizziness, dry mouth, tremor, abdominal pain, and tinnitus.

The COR-II ${ }^{48}$ study had a very similar design to COR-I, but it had only two treatment arms: placebo versus bupropion $360 \mathrm{mg}$ /day plus naltrexone SR $32 \mathrm{mg} /$ day (NB32) in a 1:2 proportion. It was conducted between December 2007 and June 2009 and published in 2013. A total of 1,496 subjects with uncomplicated obesity (BMI $30-45 \mathrm{~kg} / \mathrm{m}^{2}$ ) or with a BMI between 27 and $45 \mathrm{~kg} / \mathrm{m}^{2}$ with concomitant hypertension or dyslipidemia took part in this double-blind placebo-controlled trial. The co-primary endpoints were the percentage of weight change and the proportion achieving a 5\% weight loss at week 28. A greater weight loss was observed 
with NB32 versus placebo at week $28(-6.5 \%$ vs $-1.9 \%$; $P<0.001)$. There was an extension to 56 weeks, and patients who had not achieved a weight loss greater than $5 \%$ by week 28 were re-randomized to NB32 or bupropion $360 \mathrm{mg} /$ day plus naltrexone SR $48 \mathrm{mg}$ /day. There were no significant differences between these groups. Regarding safety, there was an SAE in $2.1 \%$ of patients in the NB32 group, including one episode of seizures and one of myocardial infarction, in front of $1.4 \%$ of patients with an SAE in the placebo group. The most frequent AEs related to the treatment were nausea, headache, and constipation.

Regarding other endpoints, which have mainly been focused on cardiovascular risk markers, the overall effect of the naltrexone/bupropion combination has been positive over lipid profile and insulin resistance. In the COR-II study, ${ }^{48}$ at week 28 , change in low-density lipoprotein was -4.4 versus $0.0 \mathrm{mg} / \mathrm{dL}$, change in triglycerides was $-7.3 \%$ versus $-1.4 \%$, change in high-density lipoprotein (HDL) was +1.2 versus -1.4 $\mathrm{mg} / \mathrm{dL}$, and change in homeostatic model assessment-insulin resistance index was $-16.4 \%$ versus $-4.2 \%$ for NB32 versus placebo, respectively. In a Phase II sub-study, approximately $78 \%$ of weight loss with the combination was due to loss of adipose tissue, and the proportion of subcutaneous and visceral adiposity loss was similar at week $24 .{ }^{47}$ This is comparable to the pattern of weight loss accomplished with diet and exercise.

However, these positive effects were not observed for blood pressure. In the COR-II study, ${ }^{48}$ at week 28 , change in systolic blood pressure was -0.9 versus $-1.2 \mathrm{mmHg}(P=0.055)$ and change in diastolic blood pressure was +0.2 versus $-0.7 \mathrm{mmHg}$ $(P<0.05)$ for NB32 versus placebo, respectively. Heart rate was also increased by an average of $1 \mathrm{bpm}$ in the NB group. However, the normal 24-hour circadian patterns of blood pressure and heart rate were maintained over 1 year of treatment. ${ }^{43}$ These findings are consistent with the well-known pharmacological effects of bupropion on blood pressure and heart rate, but we need more information on cardiovascular outcomes. ${ }^{35}$

A Phase III trial called "Light Study", ${ }^{66}$ which has the aim of assessing the cardiovascular outcomes of the combination of bupropion and naltrexone in the treatment of obesity, is ongoing and the primary completion date is estimated to be 2017. However, a provisional analysis of the data might be performed by the end of 2014 .

\section{Human studies in different clinical situations}

A clinical trial assessing the efficacy of bupropion and naltrexone in smoking cessation and weight changes in overweight and obese smoking subjects was published in $2010 .^{32}$ Thirty patients were enrolled in the open-label and single-arm study of 24 weeks and were treated with naltrexone SR $32 \mathrm{mg}$ /day and bupropion SR $360 \mathrm{mg}$ /day. The abstinence rate achieved was $48 \%$, and patients who continued smoking significantly reduced their nicotine dose. Body weight was essentially unchanged (week 12: $-0.1 \%$; week $24:+0.4 \%$ ). The absence of the typical weight gain associated with smoking cessation should be considered a significant advance.

A clinical trial assessing the efficacy of bupropion and naltrexone in depressive symptoms and body-weight changes in overweight or obese patients with major depressive disorder was published in $2013 .{ }^{49}$ Female patients $(n=25)$ were enrolled in the open-label single-arm study of 24 weeks and treated with naltrexone SR $32 \mathrm{mg}$ /day and bupropion SR 360 mg/day. A significant improvement in MontgomeryÅsberg Depression Rating Scale score was observed and body-weight losses of $-4.0 \%$ at week 12 and $-5.3 \%$ at week 24 were shown using an ITT analysis.

\section{Conclusion}

Contrave $^{\circledR}$, a combination of bupropion and naltrexone SR, seems an interesting drug to reduce appetite and therefore induce weight loss. The mechanism of action of both drugs in combination is synergistic or at least fully additive and more effective than in monotherapy. We can conclude from the current published reports that the effectiveness of bupropion plus naltrexone in the treatment of obesity is moderate. However, a weight loss of at least 5\% was achieved in all the studies and minimal side effects were observed (mainly nausea). This weight reduction is similar to that achieved with other drugs approved for the treatment of obesity such as orlistat and sibutramine. Regarding effects other than weight loss, the combination has a positive effect on all components of the lipid profile (low-density lipoprotein, high-density lipoprotein, triglycerides) and insulin resistance. However, the lack of effect on blood pressure and the increase in heart rate of $1 \mathrm{bpm}$ caused the authorities to postpone its approval. We are waiting for the results of the ongoing trial about cardiovascular outcomes that will be finished by 2017. In our opinion, given the scarcity of drugs for obesity treatment and considering the benefits of a 5\% weight loss and benefits on the lipid profile, we wish for a favorable resolution on the cardiovascular outcomes of this combined drug.

\section{Disclosure}

The authors declare no conflicts of interest in this work. 


\section{References}

1. Ogden CL, Carroll MD, Kit BK, Flegal KM. Prevalence of obesity in the United States, 2009-2010. NCHS Data Brief. 2012;(82):1-8.

2. Finkelstein EA, Khavjou OA, Thompson H, et al. Obesity and severe obesity forecasts through 2030. Am J Prev Med. 2012;42(6):563-570.

3. Finkelstein EA, Trogdon JG, Cohen JW, Dietz W. Annual medical spending attributable to obesity: payer- and service-specific estimates. Health Aff (Millwood). 2009;28:5w822-5w831.

4. National Heart, Lung and Blood Institute (NHLBI) Obesity Education Initiative Expert Panel on the Identification, Evaluation, and Treatment of Obesity in Adults (US). Clinical Guidelines on the Identification, Evaluation, and Treatment of Overweight and Obesity in Adults: The Evidence Report. Report number 98-4083. Bethesda, MD: NHLBI; 1998. Available from: http://www.ncbi.nlm.nih.gov/books/NBK2003/. Accessed May 15, 2014.

5. Berrington de Gonzalez A, Hartge P, Cerhan JR, et al. Body-mass index and mortality among 1.46 million white adults. $N$ Engl J Med. 2010;363(23):2211-2219.

6. George M, Rajaram M, Shanmugam E. New and emerging drug molecules against obesity. J Cardiovasc Pharmacol Ther. 2014;19(1):65-76.

7. Weight-Control Information Network (WIN). Prescription Medications for the Treatment of Obesity. Bethesda, MD: National Institutes of Health; 2009. Available from: http://www.win.niddk.nih.gov/publications/PDFs/ Prescription_Medications.pdf. Accessed May 1, 2014.

8. Rodgers RJ, Tschöp MH, Wilding JP. Anti-obesity drugs: past, present and future. Dis Model Mech. 2012;5(5):621-626.

9. Ling H, Lenz TL, Burns TL, Hilleman DE. Reducing the risk of obesity: defining the role of weight loss drugs. Pharmacotherapy. 2013;33(12):1308-1321.

10. Klonoff DC, Greenway F. Drugs in the pipeline for the obesity market. J Diabetes Sci Technol. 2008;2(5):913-918.

11. Kaplan LM. Pharmacological therapies for obesity. Gastroenterol Clin North Am. 2005;34(1):91-104.

12. Halford JC, Boyland EJ, Blundell JE, Kirkham TC, Harrold JA. Pharmacological management of appetite expression in obesity. Nat Rev Endocrinol. 2010;6(5):255-269.

13. Nathan PJ, O’Neill BV, Napolitano A, Bullmore ET. Neuropsychiatric adverse effects of centrally acting antiobesity drugs. CNS Neurosci Ther. 2011;17(5):490-505.

14. Ioannides-Demos LL, Piccenna L, McNeil JJ. Pharmacotherapies for obesity: past, current, and future therapies. J Obes. 2011;2011:179674.

15. Witkamp RF. Current and future drug targets in weight management. Pharm Res. 2011;28(8):1792-1818.

16. Bray GA, Ryan DH. Drug treatment of obesity. Psychiatr Clin NAm. 2011;34(4):871-880.

17. Hiatt WR, Thomas A, Goldfine AB. What cost weight loss? Circulation. 2012;125(9):1171-1177.

18. Carter R, Mouralidarane A, Ray S, Soeda J, Oben J. Recent advancements in drug treatment of obesity. Clin Med. 2012;12(5):456-460.

19. Derosa G, Maffioli P. Anti-obesity drugs: a review about their effects and their safety. Expert Opin Drug Saf. 2012;11(3):459-471.

20. Chugh PK, Sharma S. Recent advances in the pathophysiology and pharmacological treatment of obesity. J Clin Pharm Ther. 2012;37(5):525-535.

21. Heal DJ, Gosden J, Smith SL. What is the prognosis for new centrallyacting anti-obesity drugs? Neuropharmacology. 2012;63(1):132-146.

22. Ryan DH, Bray GA. Pharmacologic treatment options for obesity: what is old is new again. Curr Hypertens Rep. 2013;15(3):182-189.

23. Boulghassoul-Pietrzykowska N, Franceschelli J, Still C. New medications for obesity management: changing the landscape of obesity treatment. Curr Opin Endocrinol Diabetes Obes. 2013;20(5):407-411.

24. Heal DJ, Gosden J, Smith SL. A review of late-stage CNS drug candidates for the treatment of obesity. Int J Obes (Lond). 2013;37(1): 107-117.

25. Howland RH. Therapies for obesity and medication-associated weight gain. J Psychosoc Nurs Ment Health Serv. 2013;51(5):13-16.
26. Rueda-Clausen CF, Padwal RS, Sharma AM. New pharmacological approaches for obesity management. Nat Rev Endocrinol. 2013;9(8):467-478.

27. Clapper JR, Athanacio J, Wittmer C, et al. Effects of amylin and bupropion/naltrexone on food intake and body weight are interactive in rodent models. Eur J Pharmacol. 2013;698(1-3):292-298.

28. Greenway FL, Whitehouse MJ, Guttadauria M, et al. Rational design of a combination medication for the treatment of obesity. Obesity (Silver Spring). 2009;17(1):30-39.

29. Lee MW, Fujioka K. Naltrexone for the treatment of obesity: review and update. Expert Opin Pharmacother. 2009;10(11):1841-1845.

30. Plodkowski RA, Nguyen Q, Sundaram U, Nguyen L, Chau DL, St Jeor S. Bupropion and naltrexone: a review of their use individually and in combination for the treatment of obesity. Expert Opin Pharmacother. 2009;10(6):1069-1081.

31. Greenway FL, Dunayevich E, Tollefson G, et al; NB-201 Study Group. Comparison of combined bupropion and naltrexone therapy for obesity with monotherapy and placebo. J Clin Endocrinol Metab. 2009;94(12):4898-4906.

32. Wilcox CS, Oskooilar N, Erickson JS, et al. An open-label study of naltrexone and bupropion combination therapy for smoking cessation in overweight and obese subjects. Addict Behav. 2010;35(3):229-234.

33. Naltrexone/bupropion: Contrave(R); naltrexone SR/bupropion SR. Drugs R D. 2010;10(1):25-32.

34. Citrome L. Miracle pills for weight loss: what is the number needed to treat, number needed to harm and likelihood to be helped or harmed for naltrexone-bupropion combination? Int J Clin Pract. 2010;64(11):1462-1465.

35. Astrup A. Is cardiometabolic risk improved by weight-loss drugs? Lancet. 2010;376(9741):567-568.

36. Greenway FL, Fujioka K, Plodkowski RA, et al; COR-I Study Group. Effect of naltrexone plus bupropion on weight loss in overweight and obese adults (COR-I): a multicentre, randomised, double-blind, placebocontrolled, phase 3 trial. Lancet. 2010;376(9741):595-605.

37. New obesity pill: new hopes, old fears. Lancet. 2010; 376(9758):2042.

38. Mercer SL. ACS chemical neuroscience molecule spotlight on contrave. ACS Chem Neurosci. 2011;2(9):484-486.

39. Katsiki N, Hatzitolios AI, Mikhailidis DP. Naltrexone sustained-release (SR) + bupropion SR combination therapy for the treatment of obesity: 'a new kid on the block'? Ann Med. 2011;43(4):249-258.

40. Ornellas T, Chavez B. Naltrexone SR/Bupropion SR (Contrave): A New Approach to Weight Loss in Obese Adults. P T. 2011;36(5):255-262.

41. Halpern B, Faria AM, Halpern A. Bupropion/naltrexone fixed-dose combination for the treatment of obesity. Drugs Today (Barc). 2011;47(8):575-581.

42. Billes SK, Greenway FL. Combination therapy with naltrexone and bupropion for obesity. Expert Opin Pharmacother. 2011;12(11): 1813-1826.

43. Plutzky J, Chilton R, Still C, Burns C, Kim D, Dunayevich E. Weight loss, blood pressure, pulse and circadian patterns with naltrexone sustained-release/Bupropion sustained-release combination therapy for obesity. J Am Coll Cardiol. 2011;57(14s1):E517.

44. Reece AS. Hypothalamic opioid-melanocortin appetitive balance and addictive craving. Med Hypotheses. 2011;76(1):132-137.

45. Makowski CT, Gwinn KM, Hurren KM. Naltrexone/bupropion: an investigational combination for weight loss and maintenance. Obes Facts. 2011;4(6):489-494.

46. Wadden TA, Foreyt JP, Foster GD, et al. Weight loss with naltrexone SR/ bupropion SR combination therapy as an adjunct to behavior modification: the COR-BMOD trial. Obesity (Silver Spring). 2011;19(1):110-120.

47. Smith SR, Fujioka K, Gupta AK, et al. Combination therapy with naltrexone and bupropion for obesity reduces total and visceral adiposity. Diabetes Obes Metab. 2013;15(9):863-866.

48. Apovian CM, Aronne L, Rubino D, et al; COR-II Study Group. A randomized, phase 3 trial of naltrexone SR/bupropion SR on weight and obesity-related risk factors (COR-II). Obesity (Silver Spring). 2013;21(5):935-943. 
49. McElroy SL, Guerdjikova AI, Kim DD, et al. Naltrexone/Bupropion combination therapy in overweight or obese patients with major depressive disorder: results of a pilot study. Prim Care Companion CNS Disord. 2013;15(3):pii:PCC.12m01494.

50. Wang GJ, Tomasi D, Volkow ND, et al. Effect of combined naltrexone and bupropion therapy on the brain's reactivity to food cues. Int J Obes (Lond). 2014;38(5):682-688.

51. Woods SC, D'Alessio DA. Central control of body weight and appetite. J Clin Endocrinol Metab. 2008;93(11 Suppl 1):S37-S50.

52. Gadde KM, Parker CB, Maner LG, et al. Bupropion for weight loss: an investigation of efficacy and tolerability in overweight and obese women. Obes Res. 2001;9(9):544-551.

53. Anderson JW, Greenway FL, Fujioka K, Gadde KM, McKenney J, O’Neil PM. Bupropion SR enhances weight loss: a 48-week doubleblind, placebo-controlled trial. Obes Res. 2002;10(7):633-642.

54. Lobmaier PP, Kunøe N, Gossop M, Waal H. Naltrexone depot formulations for opioid and alcohol dependence: a systematic review. CNS Neurosci Ther. 2011;17(6):629-636.

55. Naltrexone hydrochloride tablets USP $50 \mathrm{mg}$ [prescribing information]. St Louis, MO: Mallinckrodt. Available from: http://www.mallinckrodt. com/WorkArea/DownloadAsset.aspx?id=1943. Accessed August 1, 2014.

56. Holtzman SG. Suppression of appetitive behavior in the rat by naloxone: lack of effect of prior morphine dependence. Life Sci. 1979;24(3):219-226.

57. Yeomans MR, Gray RW. Opioid peptides and the control of human ingestive behaviour. Neurosci Biobehav Rev. 2002;26(6):713-728.

58. Fantino M, Hosotte J, Apfelbaum M. An opioid antagonist, naltrexone, reduces preference for sucrose in humans. Am J Physiol. 1986; 251(1 Pt 2):R91-R96.
59. Spiegel TA, Stunkard AJ, Shrager EE, O’Brien CP, Morrison MF, Stellar E. Effect of naltrexone on food intake, hunger, and satiety in obese men. Physiol Behav. 1987;40(2):135-141.

60. Atkinson RL, Berke LK, Drake CR, Bibbs ML, Williams FL, Kaiser DL. Effects of long-term therapy with naltrexone on body weight in obesity. Clin Pharmacol Ther. 1985;38(4):419-422.

61. Maggio CA, Presta E, Bracco EF, et al. Naltrexone and human eating behavior: a dose-ranging inpatient trial in moderately obese men. Brain Res Bull. 1985;14(6):657-661.

62. Malcolm R, O'Neil PM, Sexauer JD, Riddle FE, Currey HS, Counts C. A controlled trial of naltrexone in obese humans. Int $J$ Obes. 1985;9(5):347-353.

63. de Zwaan M, Mitchell JE. Opiate antagonists and eating behavior in humans: a review. J Clin Pharmacol. 1992;32(12):1060-1072.

64. Mitchell JE, Morley JE, Levine AS, Hatsukami D, Gannon M, Pfohl D. High-dose naltrexone therapy and dietary counseling for obesity. Biol Psychiatry. 1987;22(1):35-42.

65. Korner J, Leibel RL. To eat or not to eat - how the gut talks to the brain. N Engl J Med. 2003;349(10):926-928.

66. Orexigen Therapeutics, Inc. Cardiovascular Outcomes Study of Naltrexone SR/Bupropion SR in Overweight and Obese Subjects With Cardiovascular Risk Factors (The Light Study) In: ClinicalTrials.gov [website on the Internet]. Bethseda, MD: US National Library of Medicine; 2012 [updated May 20, 2014]. Available from: http://clinicaltrials.gov/show/ NCT01601704. NLM identifier: NCT01601704. Accessed June 6, 2014.
Drug Design, Development and Therapy

\section{Publish your work in this journal}

Drug Design, Development and Therapy is an international, peerreviewed open-access journal that spans the spectrum of drug design and development through to clinical applications. Clinical outcomes, patient safety, and programs for the development and effective, safe, and sustained use of medicines are a feature of the journal, which

\section{Dovepress}

has also been accepted for indexing on PubMed Central. The manuscript management system is completely online and includes a very quick and fair peer-review system, which is all easy to use. Visit http://www.dovepress.com/testimonials.php to read real quotes from published authors

Submit your manuscript here: http://www.dovepress.com/drug-design-development-and-therapy-journal 